\title{
THE CREATIVITY OF SOCIETY MAKING RITUAL BECOMES SHOW ART: TRANSFORMATION OF RATOK BAWAK MEANING ON MINANGKABAU SOCIETY, INDONESIA
}

\author{
Nurwani NURWANI (D) ${ }^{1,}$, Bakhrul Khair AMAL ${ }^{2}$, Abdurahman ADISAPUTERA ${ }^{3}$, \\ Muhammad RIDWAN ${ }^{4}$ \\ 1, ${ }^{3}$ State University of Medan, Faculty of Language and Arts, Department of Indonesian Literature, \\ Jl. William Iskandar Ps. V, Medan, 20221, Indonesia \\ ${ }^{2}$ State University of Medan, Faculty of Social Sciences, Department of Anthropology, Jl. William \\ Iskandar Ps. V, Medan, 20221, Indonesia \\ ${ }^{4}$ State Islamic University of North Sumatra, Faculty of Tarbiyah, English Department \\ Jl. William Iskandar Ps. V, Medan, 20221, Indonesia
}

Received 15 May 2019; accepted 23 May 2020

\begin{abstract}
Using qualitative method and hermeneutical approach, this research examines the ratok bawak bewailing tradition of Minangkabau cultural ethnicity in Bukik Limbuku region, Payakumbuh town, Sumatra, Indonesia. This region uses the Indonesian language, Minangkabau tradition and follows the matrilineal system. They are led by a headman, administration is done according to custom and ratok bawak is used especially when burying a region headman. However, Hans-Georg Gadamer's transformation theory found in his book titled Truth and Method (German: Wahrheit und Methode, first edition in 1960) has transformed this ritual into an art capable of influencing its original meaning. Data were collected by observation, interview, documentation, and reconstruction, and were analyzed by interpretative and qualitative descriptive analysis. Results show that though the ratok bawak had expounded the meaning of sadness, solidarity, education, politeness, prestige and discord, the transformed ratok bawak illustrates the meaning of aesthetics, education (norm, tradition, and social), imagination, expressive creativity, creation and appreciation.
\end{abstract}

Keywords: ratok bawak, region, ritual, show art, transformation.

\section{Introduction}

Indonesia is a country with so many ethnic groups and various traditions, one of such tradition is the ratok bawak or the bewailing tradition which is usually related to death. The ratok bawak comes from Minangkabau in Bukik Limbuku region of Payakumbuh town. Ratok bawak is undertaken as a death ritual especially for a penghulu (headman) (Hafazah et al., 2015). The penghulu or headman has some important roles to play in society life in

*Corresponding author. E-mail: nurwanidr90@gmail.com

This is an Open Access article distributed under the terms of the Creative Commons Attribution License (http://creativecommons. org/licenses/by/4.0/), which permits unrestricted use, distribution, and reproduction in any medium, provided the original author and source are credited. 
Minangkabau. A headman is a smart person that is respected by the society and is given the title of Datuk, Minangkabau.

The Bukik Limbuku region follows lareh koto piliang congruent system; here penghulu pucuak or headman is regarded as a King (Dobbin, 2017). The harmony of Lareh Koto Piliang sovereignty is in a King's hand where respectful greeting comes from the society and every command comes from the King known as titik dari ate. Aphorism says "bapucuak bulek, baurek tunggang" which means that the highest power is with the penghulu pucuak who decides regulations and leads the nephews with penghulu suku or penghulu andiko and his members. The position and roles of the penghulu as custom leader is organized in the Minangkabau custom, and he is appointed by the entire members of his society, based on custom formulation. The duties and roles of the penghulu is to be a patron for his society, a judge that inquires into the problems and proffers solution and to be the hope and support of his community in overcoming their societal problems. This is how important he is to the society, so his death brings sadness to the society (Hamka, 1985). This is why his death ritual is undertaken in a special way. As a product from the social culture in Minangkabau, ratok bawak relates to a lamentation that contains sadness and anxiety. Overtime, the ratok bawak has experienced some changes and transformations to become a show art, because of the various changes that occurred in the Minangkabau society. These changes were caused by factors of belief or religion, social dynamics, traditional flexibilities, knowledge development, modern technology, social conditions, change from agrary society to industrial society and government system.

Traditional ceremonies which are closely related to religious rituals are called rites. Rites are the tools with which religious people make changes. Rites are also said to be symbolic of religion, and ritual could be said to be "religion and action" (Ghazali, 2011). Religious rituals are carried out by the community based on the beliefs held by the community, this kind of belief encourages people to perform various actions aimed at seeking contact with the supernatural world of the ruler of nature through rituals, both religious rituals (religious ceremonies) or other traditional rituals that are perceived by the society at critical moments, which can bring about magical dangers, misery and diseases to humans and plants (Koentjaraningrat, 1985).

The implementation of traditional ceremonies and religious rituals that are based on supernatural powers are still carried out by some groups of people in Indonesia, whether in the form of death rituals, thanksgiving or slametan rituals, rituals to reject reinforcements, ruwatan rituals, and so forth (Marzuki \& Soehardi, 2015). These rituals have become a tradition and have become part of the daily life of most people because they have been passed down from generation to generation by their ancestors to the next generation.

\section{Review of literature}

\subsection{Transformation of the ratok bawak}

The transformation that happened to the ratok bawak (see Figure 1) caused a whole lot of functional change from its ritual aspects to becoming a show art. Function and form change can influence the change of meaning. To be able to understand the changes that happened to 
The Transformation Process of the Ratok Bawak

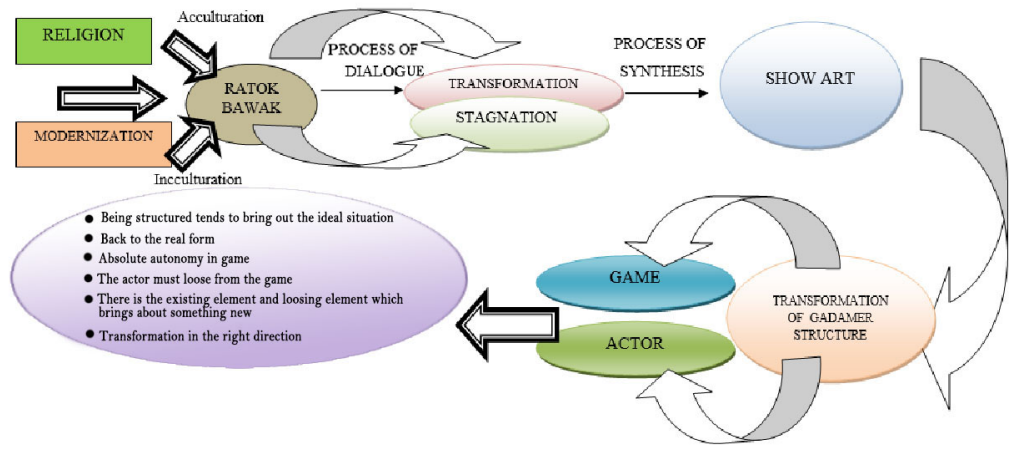

Picture 1: Transformation process of the Ratok Bawak

Figure 1. Transformation process of the ratok bawak (source: created by authors)

the ratok bawak ritual, we need to understand that these changes were supported by a transformation theory. There were transformation changes in form, shape and cultural tradition character that resulted from several factors from the Bukik Limbuku society. These changes were natural in nature while some were parallel to natural laws that has been duly underlined. The entire changes that occurred in shape, form, character, etc. have feedbacks that are given by individuals and groups. The occurrence of such transformation is not without causes, as it was influenced by some factors such as cultures, contact to the other culture, heterogeneous society, social disorder, and social change itself (Shils, 1983).

Our mainstream culture was centered around the partnership model but following a period of chaos and cultural disruption, there was a fundamental shift towards the dominator model. The greater archaeological data which are available on ancient civilizations made it possible to document this shift in more details through the analysis of prehistoric cultural evolution (Eisler, 1987). The change processes in the ratok bawak happened with the reproduction and transformation processes. Reproduction process of the ratok bawak has to do with indulging in several forms of repeating, and accessing once again the results of everyting that has become acceptable as cultural inheritance from our great grandparents. In this case, cultural inheritance of our daily life includes tangible materials that relate to our existance and other materials that are not tangible but are also related to our existence such as, norm and values. The transformation process which happened to the creation process of ratok bawak being something new resulted through the advent of knowledge and technology. Thus, ratok bawak has experienced transformation which could also be viewed from the local reproduction process as a show art.

Social transformation means the restructuring of all aspects of life; from culture to social relations; from politics to economy; from the way we think to the way we live. Through time, societies have been transformed from small associations of individuals tied together by instincts, need, and fear, to small communities tied together by circumstances, kinship, traditions, and religious beliefs, to nations tied together by history, politics, ideology, culture, and laws. But for most of human history, the pace of change was very slow and no transforma- 
tions in life conditions could be felt for several generations (Rabie, 2013). The ratok bawak is shown from the social cultural aspect of Minangkabau as a cultural inheritance that has been lost. Transformation process is accepted not as a deviation as the process of transformating becomes something new and it is an accustion from the reality of concept about durability. The core of phenomenon is its change process. This phenomenon needs to be understood as signs, since the transformation process in human life needs to be considered as the true process and maintained because the real meaning of life is in it. Cultural transformation takes place naturally.

In the 20th century, most cultural and social anthropologists turned to the crafting of ethnographies as one of the principle research methods of cultural anthropology. An ethnography is a piece of writing about a people, at a particular place and time. Typically, the anthropologist lives among people in another society for a period of time, simultaneously participating in and observing the social and cultural life of the group. The anthropological concept of "culture" reflects in part a reaction against earlier Western discourses based on an opposition between "culture" and "nature", according to which some human beings lived in a "state of nature". Anthropologists have argued that culture is "human nature", and that all people have a capacity to classify experiences, encode classifications symbolically (i.e. in language), and teach such abstractions to others.

This approach looks at society through a macro-level orientation, which is a broad focus on the social structures that shape society as a whole and believes that society has evolved like organisms (Tylor, 1871). This approach looks at both social structure and social functions. Functionalism addresses society as a whole in terms of the function of its constituent elements; namely norms, customs, traditions, and institutions.

Malinowski (1990) developed the ethnographic method, and Boas (1940) taught it in the United States (US). Simultaneously, Boas' students such as Kroeber (1987), Benedict (2005) and Mead (2001) drew on his conception of culture and cultural relativism to develop cultural anthropology in the US.

The ratok bawak as a show art is understood as acting, and the acting has been arranged in structure such as move, enjoy pattern, costume, property, lighting, and setting, make up and stage place. Various forms of improvisation take place with the ratok bawak tradition resulting into unexpected bewailings or moves. The ratok bawak was reconstructed in an effort to preserve the culture of wailing in the Bukik Limbuku village, by presenting ratok bawak materials, observing them from the social behavior of the nagari community, then rearranging them into a series of subtle ratok processes which are poured into the artwork. The audience is still able to relate to the acting process although there is some distance between the acting process and the audience. The ratok bawak and artwork are understood not as action role scheme, but as free acting that can create itself. The ratok bawak does not demand to be understood as it satisfies the need for a game, though it calls for an acceptance of its existance. This type of game is structured, although it depens on it played form, but its whole meaning can be represented repeatedly and the meaning can be understood. The ratok bawak has experienced transformation into being a show art or has experienced secular change from the practices of values which were regarded as sacred into becoming a secular art. 
This transformation of its ritual aspects into a show art is what is regarded as transformation. The transformation into a show art of the ratok bawak is observed from the perspective of transformation according to (Gadamer, 2010). The transformation into the structure is not just a move to another world like the art of ratok bawak which has to do with the presence of existing structures, but there is also the missing structure. The presence or absence of existing structures in the show arts have necessitated the players to try to inculcate the show into the real game, which lives in the game world itself. Transformation is considered to be a true inward transformation, not to change the charm into something as it is, but the penetration of the transformation back to the true being. The show art is the manifestation of the original art which penetrates and transform it into its original form, by presenting and maintaining the existing structure.

The creative society has been described, usually indirectly by McLuhan (1994) who through his investigations has described the media as an extension of man and as a family of artefacts where every new member changes the relations between all members. Also, Marcuse (1974) has criticized the negative social tendencies of how cultural development was influenced by technology and the media.

As the Russian theorist Bakhtin (1984) has demonstrated, at the very core of the carnival and carnivalism is the sharp juxtaposition of various different elements of human existence and life such as, public demeanour, death, and the renewal of life, which are usually kept temporally and spatially separate by the official culture. The design includes reconceptualization of the concepts of action on the concepts of action, structural and system with the aim of integrating them into new approaches (Beilharz, 2005). Reconceptualization of the concept of the action of the nagari community in relation to the ratok bawak, compiled and based on structural and systemic implementation, which begins by looking at the social practices that continue as the most important analysis.

Bakhtin (1984) explains the nature of carnival by stating that the carnival does not belong to the sphere of art. It belongs to the borderline between art and life. In reality, it is life itself, but it is shaped according to a certain pattern of play. The ratok bawak reconstruction is a past culture of the nagari community of Bukik Limbuku where an understanding of the teachings of Islam is not strong. The results of the reconstruction were put back into the form of performance art as an effort to preserve it, and this is expected to be a reinforcement of the Bukik Limbuku's nagari community's identity.

Identity is a form of self-reflection or self-reflection that comes from family, gender, culture, ethnicity and socialization process. Identity basically refers to the reflection of ourselves and other people's perceptions of us. Identity defines a person as an individual who is different in behavior, beliefs, and attitudes. The ratok bawak as a culture of wailing came to be because of the social processes that took place in the nagari which were related to kepenghuluan, and which has become an identity for the nagari community of Bukik Limbuku. Because the understanding of religion is getting stronger, the subordinate ratok starts to be abandoned, and the process of socialization begins to stop. In an effort to bring back the identity of the Bukik Limbuku nagari community, research, creation, and presentation were carried out as an effort to socialize the guinea pigs in the Minangkabau community and outside the Minangkabau. 
The transformation of the ratok bawak from a ritual into a show art is a manifestation of the cultural phenomenon which has beset the process of bewailing known as the ratok bawak. The ratok bawak is a form of bewailing culture found in the rituals of the death of the penghulu, which involves the preparation of a special space for the mother and the wives of the penghulu to express their sorrows.

Prior to this research, there were other researches into the reconstruction of the death rituals for the penghulu which were found in the Bukik Limbuku nagari community. The data obtained were used as a foundation or foundation for making the concept, works and textures of the show. The concept of cultivating works is compiled based on the phenomenon of the bewailing culture which is related to the behavior and actions of the people who own the culture, and as objects of research poured into works of art. In this context, researchers and choreographers are based on objectivity so that the pouring of data must be accompanied by the author's independence. While the behavior and actions of the community are packaged into creative stimuli, which are guided by aesthetic concepts. Subjectivity remains guided by the objectivity and authenticity of wailing cultural events that become an inspiration.

From the data and concepts that have been designed, a lot of information abound to educate dancers, actors, and musicians so that what is desired in the work can be conveyed. After dancers, actors and musicians have been able to understand these information, then they are able to continue to explore the necessary motion, narration, and music. Exploration results are arranged into a complete form of artwork. The form of art which is a series of events, begins with the emergence of a male figure as the penghulu, standing on a trap or level (an elevated place on stage), symbolizing rumah gadang. Then he slowly descends the trap or level while reading a narrative containing the Minangkabau realm, the nagari of Bukik Limbuku. Bukik Limbuku adheres to a system of solubility created by the Dutch, as a form of strategy to control the nagari. In addition, it also conveyed the position of the leader in the village.

\subsection{Minangkabau society}

The center of the Minangkabau culture is the highland of West Sumatra (WS), Indonesia. This highland is "traditionally" divided into three regions: Lima Puluh Kota Regency (WS, Indonesia), Tanah Datar Regency (WS, Indonesia) and Agam Regency (WS, Indonesia) (Kato, 2007). Minangkabau consists of nagari led by a penghulu, one of them is the Payakumbuh town Bukik Limbuku village. Nagari Bukik Limbuku adheres to the Lareh Koto Piliang system of sanity, where the pucuak chief is considered a King (Abdullah, 1986). On the basis of Lareh Koto Piliang's sovereignty, the sovereignty is in the hands of the king where worship comes from the people and all orders come down from above which are called titik from ate. As the saying goes: "bapucuak bulek, baurek tunggang" (rounded round, veined), the highest authority who is uphold by the pucuak prayer, sets the rules and leads his people together with the Tribe's penguluulu or andiko along with his assistants. Minangkabau customs have regulated the position and role of the penghulu as adat leaders (Abdullah, 1986). The chancellor is appointed by his people, in accordance with the customs' formula. The duties and roles of the penghulu are as protectors, as judges who preside over all problems and cross disputes, and as foundations of hope in overcoming the problems bothering the lives of their people. So important is the position and roles of a penghulu that his death becomes a source of sadness to his people and the death ritual is also carried out accordingly (Kato, 2007). 
During his death ritual, the prince is provided a special room for his mother and his wives to express their sadness called the ratok bawak. Loud and piercing cries are heard from the yards of those houses and from the top of the houses. Lamentations are carried out by the mother, the wives of the prince, followed by body movements which signify extreme sorrow. These lamentations continue until the body is taken to the tomb for burial.

\section{Methodology}

To understand what is hidden has been identified as the most difficult phenomenon to be known or understood, therefore; the right method is needed. This study uses cultural anthropology as branch of anthropology to focus on the study of cultural variation among humans. It is in contrast to social anthropology, which perceives cultural variation as a subset of a posited anthropological constant. Cultural anthropology has a rich methodology, including participant observation (often called fieldwork because it requires the anthropologist spending an extended period of time at the research location), interviews, and surveys (Earley \& Peterson, 2004).

Data are collected by observation, interview, literature study, documentation such as photo and ratok bawa video. Documentation of ratok bawak ritual is gotten by recontructing lost ratok bawak ritual. Data analysis is undertaken by qualitative descriptive analysis and interpretation (Endraswara, 2013).

\section{Discussion}

The procedure of a headman's death ritual at least is influenced by a system that is made by the Dutch. Everything that relates to ritual is prepared by bandaro, panglimo, dubalang, and pagawai and it begins by hitting a large drum to inform the society, to prepare equipment ritual, to appoint who will hit the talempong, and to take the weapon off. In Bukik Limbuku region, for the death of a headman, bewailing is undertaken specially, here everything is prepared basen on custom, so the wife or mother of the headmen can express her sorrows in a special way. If his wife cannot bewail, others will bewail, so ratok bawak can be undertaken. Bewailing is undertaken in the rumah gadang (traditional house, see Figure 2) and yard (see Figure 3). Bewailing in the yard is undertaken on buffalo skin or bawak, so this bewailing is called ratok bawak. To undertake a bewailing ritual is for the family of the deceased to mourn by expressing their sadness and sorrows when a headman dies. The sorrows of a mother is always acutebecause her son (headman) has passed away. Her worry cuts her out as a person with a large heart, big soul and as a smart mother who does not only think about her own sadness, but also worries about the entire society in nagari, to whom her son had served as a role model and given hope as a noble headman of a nagari society. The bewailing of a wife also has a sad connotation of worry, and hope so that the deceased headman who was her husband can be accepted by Allah comfortably. Moreover, the bewailing of a wife also contains the feeling of fight, whereby the wives who are involved in the bewailing of their deceased husband compete with each other to show who was the most loved wife of their late husband (headman). 


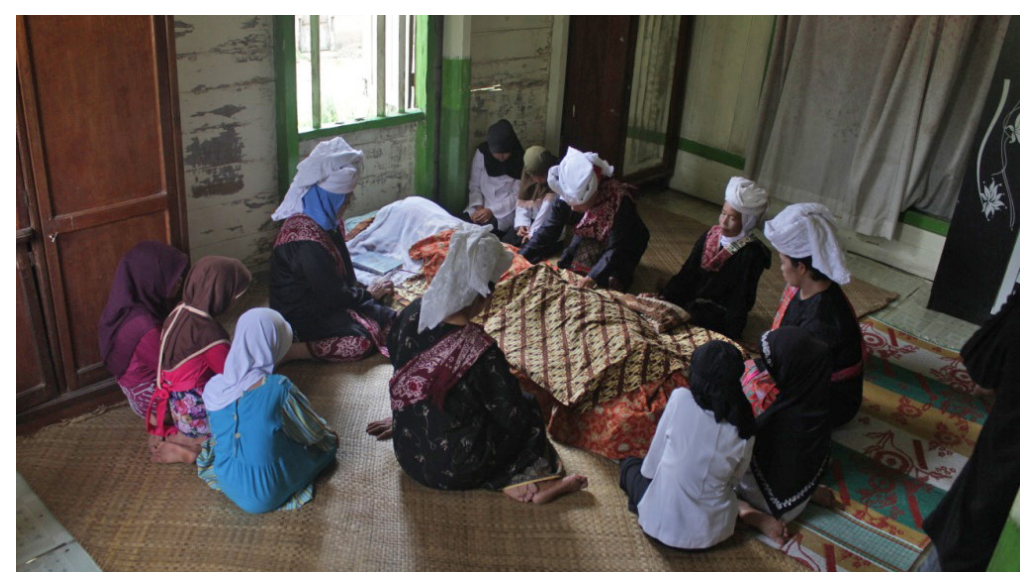

Figure 2. Bewailing on house roof (source: created by authors)

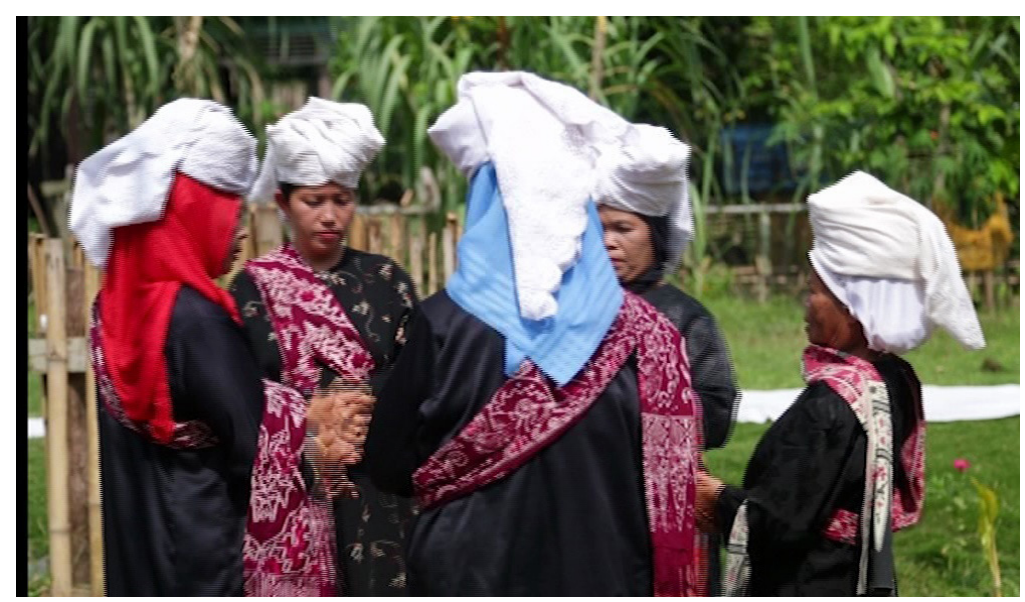

Figure 3. Bewailing in yard (source: created by authors)

The transformation that has happend to the ratok bawak ritual and turned it into a form of a show art, is an expression of the society's feeling that the partakers in the ratok bawak is entitled to become creative through his or her perception of sense and image. The feelings in ratok bawak relate to feelings of physic sensation, accusative, strong desire, stress, and strong emotions which are related to the life of the community in each region that practices the ratok bawak. The show art of the ratok bawak is not only depicted as a game that stands alone, but it also has a relation to the social life and cultural society and with cultural values in society. Besides that, there is also a relationship between the artists and the society, between the artists of ratok bawak artistic group and the tradition owners of the ratok bawak. The show art as an aspect of creativity is the ability of someone to use his/her ability to address the situation at hand. Art very relates to skill, human's activity, work of art, and aesthetics. Art is an expression of some feelings and human thinking. So, when someone wants to create 
a work of art, he/she must understand the feelings that are to become processed, organized and created as the objects/objectives of the art.

The transformation of the ratok bawak was initiated by a society that was in love with traditional culture either from Bukik Limbuku or besides Bukik Limbuku. One of the persons that followed directly to pertuatt traditional culture and introduce the new aspects of the traditional culture is Ms. Ramsani. Besides Ms. Ramsani, transformation was also undertaken by Tom Ibnur, an Indonesian mestro dancer. The transformation that was undertaken still tends to traditional patterns while Ibnur has developed in choreography and creative an idea that is found, but still maintains traditional values. Ibnur's work is supported by dancers from State University of Padang, Indonesia and Jakarta Institute of Arts, Indonesia. Besides it, Ibnur is accompanied by traditional artists from the regions who are the owners of ratok bawak. Creative idea that is found in work of Ibnur are:

1. The title becomes ambau jo imbau;

2. Work pattern is more counted and consideration is more complete;

3. Dancer is more various;

4. Music is more made up based on atmosphere that is wanted and more various;

5. Costume is adjusted to actor's position in work;

6. The move is more varied and looks sober and worked out as theme and dance concept;

7. Using level as equipment to support the work;

8. Using light by professional worker;

9. Artistic team by expert with consideration so that it is based on work need.

With the transformation that is conducted by Ms. Ramsani: same title, loosing sacred, and the form is still same with the original. Transformation of traditional culture being show art has a long process which are not easy and not always easy. Many obstacles are confronted whereas the society has agreed that ritual culture is no longer allowed, but by persevering efforts, respons and good appreciation from lovers, transformation can be accepted and finally acknowledged. Transformation of ratok bawak into a show art ambau jo imbau became a warm issue and debate at that time, and finally it was acknowledged. Thus, the transformation that was undertaken as a ritual and a phenomenon that was really practiced by the nagari society was now transformed into a show art. As mentioned by Gadamer (2010), transformation into a show art means that it has been in existence before but now it is mentioned as a game. The game according to Gadamer (2010) is not an acting that plays and still maintains the existance. From an angle of not being able to separate self from existance, it would be observed that the actor is only acting and not playing a game.

According to Gadamer, game is used to transfer meaning, through symbols either language and move that is in the game. On a show art of the ratok bawak, actors have been able to transfer meanings through played ymbols especially through the dance move, but there are still some young actors that are not able to convey the meaning of their acting to the audieance especially through the move symbol. This is because of their inability to release themselves and feel the purpose of the parts that they are acting. The existing structure of the ratok bawak can be seen in Figure 4. 


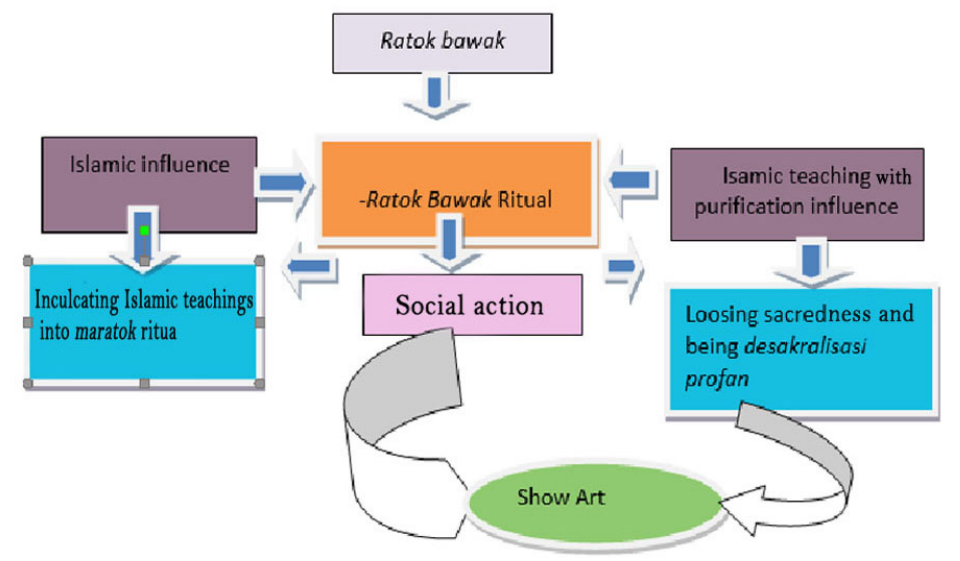

Figure 4. The existing structure of the ratok bawak ritual (source: created by authors)

\section{Conclusions}

The transformation of the ratok bawak into a show art through creativity has resulted into functions which give creative experience to the audience, so the audience gets experience and knowledge from the played game. The ratok bawak game is recognized as an imitation of reality or truth. What is imitated and contibuted from the ratok bawak becomes a show art that is formed by the creator who is represented by the actor and recognized by the audience. Therefore, the performance when presented is diffrenciated from what is imitated. What is played by the ratok bawak and recognized by audienced is formed into actions by the creator.

In the ratok bawak games, double mimesis are created which are represented by the creators and the actors. There could be a change in the meaning of sadness expression of the society with the sadness of the ratok bawak owner into a game that have some aesthetic values.

The meaning of ratok bawak ritual:

1. The meaning of ratok bawak ritual text:

- Sadness, solidarity, education, patience, prestige, discord;

- There is a meaning of contradiction from given signs;

- Relating to the sentiments of a mother or wife, the society tends to feel sentimental and this is caused by risk, fear, hopelessness of loss and the enjoyment of winning.

2. Aesthetics of the ratok bawak describes society of the past as at the time before the change began in the society and with the doctrine of normative idea.

Transformation of ratok bawak meaning:

1. There is a meaning of transformation being aesthetics, and education meaning (norm, custom and social). Moreover, there is meaning of imagination, creativity of expression, creation and appreciation;

2. Aesthetics describe the age after society experienced change, doctrine of beauty which is a creative idea that tends to communicate norm as the ratok bawak owner; 
3. Transformation tends towards Gadamer's theory of artworks as games. The show art ilau which is regarded as game are:

- Artworks as games;

- Being true form as ilau game;

- Gamer can play the game;

- The core of ilau game is a bewailing symbol;

- There is exist, there is lost and there is new;

- From spontaneity to constant;

- Reality imitation;

- Imitation becomes an acknowledged being's identity;

- Gamer in soul of game;

- As imitation from reality and being acknowledgement;

- The form of imitation of reality becomes a real truth.

\section{References}

Abdullah, T. (1986). Islam, history and social change in Minangkabau. In L. L. Thomas \& von F. BendaBeckmann (Eds.), Change and continuity in Minangkabau: local, regional, and historical perspectives on West Sumatra. Series: Monographs in International Studies: Southeast Asia Series. No. 71 (pp. 141-155). Ohio University.

Bakhtin, M. (1984). Rabelais and his world. Indiana University Press.

Beilharz, P. (2005). Teori-teori sosial: observasi kritis terhadap para filosof terkemuka. Pustaka Pelajar.

Benedict, R. (2005). Patterns of culture. Houghton Mifflin Company.

Boas, F. (1940). Race, language, and culture. The University of Chicago Press.

Dobbin, Ch. (2017). Islamic revivalism in a changing peasant economy: Central Sumatra, 1784-1847. Series: Routledge Library Editions: Islam, State and Society. Routledge. https://doi.org/10.4324/9781315398181

Earley, P. Ch., \& Peterson, R. S. (2004). The elusive cultural chameleon: cultural intelligence as a new approach to intercultural training for the global manager. Academy of Management Learning and Education, 3(1), 100-115. https://doi.org/10.5465/amle.2004.12436826

Eisler, R. (1987). Woman, man, and the evolution of social structure. World Futures: The Journal of New Paradigm Research, 23(1-2), 79-92. https://doi.org/10.1080/02604027.1987.9972039

Endraswara, S. (2013). Teori Kritik Sastra: Prinsip, Falsafah, dan Penerapan. Center for Academic Publishing Services.

Gadamer, H.-G. (2010). Truth and method. Continuum.

Ghazali, A. M. (2011). Antropologi Agama: Upaya Memahami Keragaman Kepercayaan, Keyakinan, Dan Agama. Alfabeta.

Hafazah, S., Baidar, \& Gusnita, W. (2015). Makanan Adat Pada Acara Manyaratuih Hari Di Nagari Pakandangan Kecamatan Enam Lingkung. Program Studi Pendidikan Kesejahteraan Keluarga. Jurusan Kesejahteraan Keluarga, Fakultas Teknik, Universitas Negeri. https://media.neliti.com/media/ publications/72138-ID-makanan-adat-pada-acara-manyaratuih-hari.pdf

Hamka. (1985). Islam dan Adat Minangkabau. Pustaka Panjimas.

Kato, T. (2007). Matriliny and migration: evolving Minangkabau traditions in Indonesia. Equinox Publishing.

Koentjaraningrat. (1985). Ritus Peralihan di Indonesia. Balai Pustaka.

Kroeber, A. L. (1987). The nature of culture. University of Chicago Press. 
Malinowski, B. (1990). A scientific theory of culture and other essays. University of North Carolina Press. Marcuse, H. (1974). Eros and civilization: a philosophical inquiry into freud. Beacon Press.

Marzuki, N. N., \& Soehardi, M. A. (2015). Simbolisme Dalam Upacara Adat: Kajian Terhadap Upacara Adat Mappogau Hanua Pada Masyarakat Adat Karampuang di Kabupaten Sinjai, Sulawesi Selatan. Tesis. Ilmu Antropologi. Universitas Gadjah Mada [unpublished source].

McLuhan, M. (1994). Understanding Media: The Extensions of Man. The Massachusetts Institute of Technology Press.

Mead, M. (2001). Coming of age in Samoa. Series: Perennial Classics. William Morrow Paperbacks.

Rabie, M. (2013). Saving capitalism and democracy. Palgrave Macmillan. https://doi.org/10.1057/9781137321312

Shils, E. (1983). Tradition. The University of Chicago Press.

Tylor, E. B. (1871). Primitive culture: researches into the development of mythology, philosophy, religion, art, and custom. John Murray.

\title{
VISUOMENĖS KŪRYBIŠKUMAS RITUALUI TAMPANT ŠOU MENU: RATOK BAWAK PRASMĖS TRANSFORMACIJOS MINANGKABAU VISUOMENĖJE (INDONEZIJA)
}

\author{
Nurwani NURWANI, Bakhrul Khair AMAL, Abdurahman ADISAPUTERA, \\ Muhammad RIDWAN
}

\begin{abstract}
Santrauka
Taikant kokybinį metodą ir remiantis hermeneutiniu požiūriu, šiame tyrime nagrinèjama apraudojimo tradicija ratok bawak, gyvuojanti minangkabau kultūrinejje etninejje grupèje, įsikūrusioje Bukik Limbuku regione (Pajakumbu miestelis, Sumatra, Indonezija). Šiame regione vartojama indoneziečiu kalba, laikomasi minangkabau tradicijų ir gyvuoja matrilinijine sistema. Regiono gyventojai turi savo vadą, jo valdymas grindžiamas paprotine teise, o ratok bawak tradicija taikoma tik laidojant regiono vadą. Tačiau, remiantis Hanso-Georgo Gadamerio transformacijos teorija, pristatoma knygoje Tiesa ir Metodas (vok. Wahrheit und Methode, pirmasis leidimas 1960 m.), šis ritualas transformuojamas ị meną, turinčiu ịtakos jo pirminei prasmei. Duomenys buvo renkami atliekant stebejimus, imant interviu, taikant dokumentavimą ir rekonstravimą, o analizuojami pasitelkiant interpretacijos ir kokybinio aprašymo metodus. Rezultatai atskleidžia, kad, nors ratok bawak tradicijai buvo priskiriamos liūdesio, solidarumo, ugdymo, mandagumo, prestižo ir nesantaikos prasmès, tačiau transformuotoji ratok bawak tradicija iliustruoja estetikos, išsilavinimo (normų, tradicijų ir socialumo), vaizduotès, išraiškingo kūrybiškumo, kūrybos ir pripažinimo prasmes.
\end{abstract}

Reikšminiai žodžiai: ratok bawak, regionas, ritualas, šou menas, transformacija. 